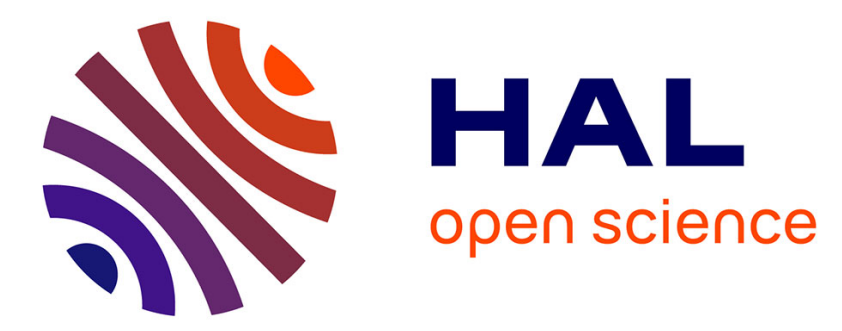

\title{
Evaluation of the relative roles of a vegetative filter strip and a biofiltration swale in a treatment train for road runoff
}

Kelsey Flanagan, Philippe Branchu, David Ramier, Marie-Christine Gromaire

\section{- To cite this version:}

Kelsey Flanagan, Philippe Branchu, David Ramier, Marie-Christine Gromaire. Evaluation of the relative roles of a vegetative filter strip and a biofiltration swale in a treatment train for road runoff. Water Science and Technology, 2017, 75 (4), pp.987-997. 10.2166/wst.2016.578 . hal-01490940v2

\section{HAL Id: hal-01490940 \\ https://hal.science/hal-01490940v2}

Submitted on 31 Mar 2017

HAL is a multi-disciplinary open access archive for the deposit and dissemination of scientific research documents, whether they are published or not. The documents may come from teaching and research institutions in France or abroad, or from public or private research centers.
L'archive ouverte pluridisciplinaire HAL, est destinée au dépôt et à la diffusion de documents scientifiques de niveau recherche, publiés ou non, émanant des établissements d'enseignement et de recherche français ou étrangers, des laboratoires publics ou privés.

\section{(ㅇ)(1) $\$$}

Distributed under a Creative Commons Attribution - NonCommercial - NoDerivatives| 4.0 
1 Title: Evaluation of the relative roles of a vegetative filter strip and a

2 biofiltration swale in a treatment train for road runoff

3 Short title: Relative roles of a vegetative filter strip and a biofilter in a road

4 runoff treatment train

5 Authors : Kelsey Flanagan*, Philippe Branchu**, David Ramier**, Marie-Christine

6 Gromaire*

7 *Laboratoire Eau, Environnement et Systèmes Urbaines, Université de Paris-Est - Ecole des Ponts Paris-

8 Tech, 6-8 avenue Blaise Pascal, Cité Descartes, Champs-sur-Marne, 77455, Marne-la-Vallée Cedex 2,

9 France

kelsey.flanagan@enpc.fr

** Cerema/DTer Ile-de-France, 12 rue Teisserenc de Bort, 78190 Trappes, France

\section{ABSTRACT}

In order to determine the relative importance of a vegetative filter strip and a biofiltration swale in a treatment train for road runoff, US EPA SWMM was used to model infiltration and runoff from the filter strip. The model consisted of a series of subcatchments representing the road, the filter strip and the side slopes of the swale. Simulations were carried out for different rain scenarios representing a variety of climatic conditions. In addition, a sensitivity analysis was conducted for the model's different parameters (soil characteristics and initial humidity, roughness, geometry...). This exercise showed that for the system studied, the majority of road runoff is treated by the filter strip rather than the biofiltration swale, an effect observed especially during periods of low-intensity rainfall. Additionally, it was observed that the combination of infiltration of road runoff in the filter strip and direct rainfall on the system leads to a significant and variable dilution of the runoff reaching the swale. This result has important implications for evaluating the treatment efficiency of the system. 
New urban water management paradigms such as low impact development (LID), sustainable drainage systems (SuDS) and water sensitive urban design (WSUD) recommend managing stormwater close to the source through on-site integrated control measures encouraging infiltration and evapotranspiration, thereby maintaining the hydrologic behavior of a site close to its natural state (Fletcher et al. 2014). These techniques contribute to water security by managing the flooding risk while maintaining or restoring base flows in streams (Hamel et al., 2013) and groundwater recharge (Stephens et al., 2012). They also contribute to water quality preservation by reducing the discharge of pollutant loads to water bodies for the chronic, nonpoint source pollution associated with urban stormwater (Sage et al., 2015) and, in the case of roadways, by confining pollution potentially generated by automobile accidents.

The chronic contamination of road runoff by such pollutants as suspended solids, metals, nutrients, organic carbon and oil and grease has long been a concern within the water quality community (Kayhanian et al. 2012). Recent research has also revealed the presence of organic micropollutants in this type of water (Kalmykova et al. 2013), as well as a certain toxicity toward aquatic organisms (Dorchin \& Shanas 2010).

In France, road constructors are required to demonstrate that pollution generated by new or renovated infrastructures will not degrade the quality of water resources. The current national design guide suggests grassed ditches or swales as a strategy for particle retention (Cavaillès et al. 2007). While sedimentation and filtration as water moves through dense vegetation have been shown to improve water quality in traditional grassed swales (Stagge et al. 2012; Winston et al. 2012), some studies have shown this effect to be unreliable, varying greatly between storm events. (Bäckström et al. 2006; Leroy et al. 2016)

In order to improve particle retention and depollution while imitating predevelopment hydrology, an emerging technique currently being studied for particularly polluted sites is that of a swale with check dams and a planted filter medium, where treatment relies on filtration occurring as water infiltrates into the bottom of the swale. This LID technique is already widely applied in the international context and corresponds to a linear bioretention system (Roy-Poirier et al. 2010) or what Hatt et. al (2009) refer to as a biofiltration swale.

Because of the presence of the base layers of the road structure as well as safety concerns, these ditches cannot be located in immediate proximity to the road surface. Instead, the base of the road structure is often 
covered with planted topsoil, forming a vegetated road shoulder over which road runoff flows before continuing on to other treatment devices, such as a biofiltration swale. In this case, the shoulder acts as a vegetative filter strip, pretreating water before it reaches subsequent treatment systems. Internationally, in order to prevent clogging in biofiltration systems, many design guides recommend pretreating road runoff with a vegetative filter strip (Hatt et al. 2009; CIRIA 2015). Like grassed swales, vegetative filter strips (VFS) remove particulate pollutants through sedimentation and filtration and have been shown to effectively remove suspended solids and metals, while infiltration in the strip's soil will result in a reduction in runoff volume (Barrett et al. 1998; Li et al. 2008).

In France, however, practitioners rarely consider vegetated shoulders to play a role in water treatment and they are not included in the current national guide for road pollution management (Cavaillès et al., 2007). Neither are they included in the guide for the hydraulic design of road runoff management structures (Gaillard et al., 2006). Their role is generally not taken into account in treatment system design and the extent of infiltration in this part of the system as well as its role in pollutant flux management is poorly understood.

Overly simplistic representations of VFS, generally as surface flow devices with no infiltration accounted for, can also be found in various international design manuals. Akan and Attabay (2016) cite state design manuals from lowa, Washington, New Jersey and Pennsylvania which base VFS sizing only on surface flow considerations. The United Kingdom SuDS manual specifies ranges of acceptable slopes and filter widths, maximal impermeable area width, and maximal flow depth and velocity but does not take into account the hydraulic conductivity of soil (CIRIA 2015). Similarly, a guide from New Zealand recommends a hydraulic residence time calculated using sheet flow velocity and filter width in order to encourage pollutant removal, while qualitatively mentioning that permeable soils will increase system efficiency (Auckland Regional Council 2003). Indeed, neglecting the extent of infiltration in a VFS when sizing devices is a conservative approach, which will tend to overestimate system runoff and underestimate pollutant removal. However, it may also lead to a conception of the system which exaggerates the importance of downstream devices in managing pollutant and hydraulic loads, leading to a suboptimal overall design and possible maintenance issues.

Several mathematical models of vegetative filter strips can be found in the scientific literature (Akan 2014; Deletic 2001; Muñoz-Carpena et al. 1999). While they vary in their representation of sediment transport, these models all represent system hydrology using a kinematic wave formulation for overland flow and Green-and- 
Ampt model of infiltration. These modeling studies have also all focused on modeling runoff from VFS at an event scale for either real events or design events.

In addition, while they have been successful in research applications, they have not been widely applied in an operational context. In order to make model results more accessible to practitioners, Akan and Atabay (2016) used such a model to create a set of dimensionless charts to be used as an aid for the hydrologic design of vegetative filter strips. While these charts may help to improve simplified design procedures by including the effect of infiltration, they are limited to a certain number of design configurations and were calculated using constant rain intensities and do not, therefore, provide information about system behavior for real rain events. In the present study, a simplified approach of VFS modeling using US EPA SWMM is applied. This model, widely used by practitioners, is user-friendly and open source. While the model presented in this paper only represents the road surface, the vegetated road shoulder (hereafter referred to as a vegetative filter strip or VFS) and the side-slope of the biofiltration swale, SWMM is capable of representing much larger systems and the VFS model could easily be integrated into a more global model of the stormwater management infrastructure of an urban area.

Specifically, this work seeks to evaluate the role of a VFS and side-slope in managing road runoff in a treatment train, comparing the proportions of water treated by this part of the system with those treated by a downstream biofiltration swale. It further aims to identify the environmental and design parameters having the greatest influence on these proportions. The current study is unique in its attempt to simulate the hydrologic behavior of a VFS over a long period (4 years) typical of a given climate and in its consideration of the implications of this behavior on the design, evaluation and maintenance of downstream treatment devices.

\section{METHODS}

\section{The Compans case study}

The model constructed represents an experimental site located in Compans, a community close to Charles de Gaulle Airport in the Paris region of France. The site, presented in Figure 1, consists of a four-lane roadway with a daily traffic of 11,000 vehicles in each direction and a sustainable drainage system (SuDS) designed to handle the road runoff. At the side of the road, stormwater from two traffic lanes runs off directly onto a vegetative 

micropollutants in the system.

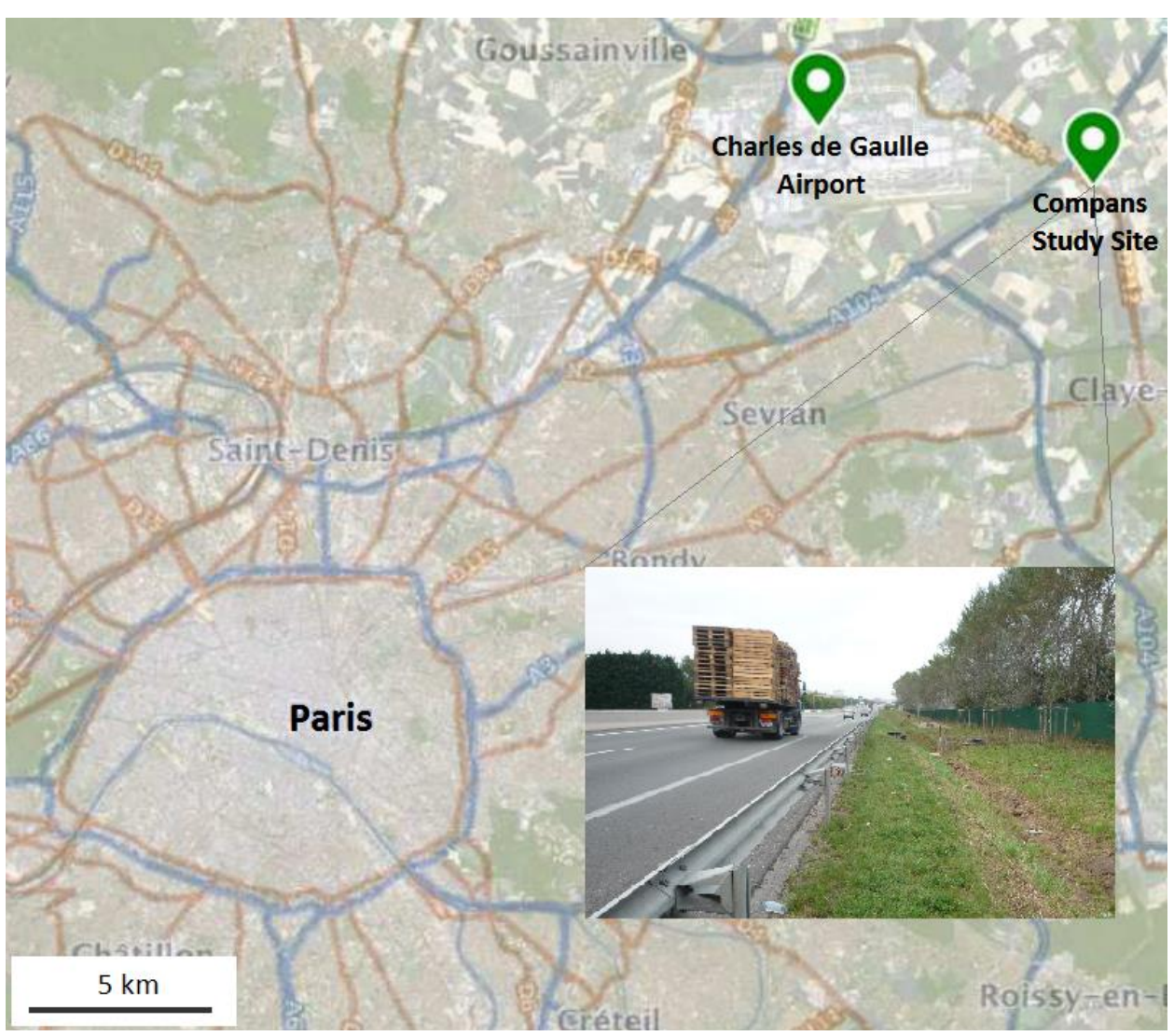

Figure 1: Location map and photograph of the Compans case study site

Two versions of this system are being studied: one in which the soil of the vegetative filter strip and the sideslope has been replaced by the filter medium and in which both the filter strip and the swale are drained (but not lined) using a sheet drain and one in which typical topsoil (silt loam texture) is used in the vegetative filter strip and the side-slope and neither the filter strip nor the swale are drained. During the design of the system, special attention was given to the choice of both the soil and the plants in the swale in order to optimize depollution processes.

However, after three years of operation, observations indicate that less water is present in the swale than expected: the swale's drain has nearly always been dry and plants requiring humid conditions have not 
survived. The present modeling exercise was therefore undertaken in order to investigate the hypothesis that most runoff infiltrates into the vegetative filter strip and side-slope of the system rather than reaching the swale.

\section{Vegetative filter strip runoff modeling}

The system was modeled within US EPA SWMM 5.1 (Rossman 2015) as a series of rectangular subcatchments representing the road, the vegetative filter strip and the side-slope of the swale as suggested by Gironás et al. (2009). The outlet of the side-slope represents the runoff reaching the biofilter of the swale. . This model represents each sub-catchment as a non-linear reservoir, taking into account the basic hydrologic processes occurring in the system (rainfall, run-on, run-off, infiltration, evaporation) in a simplified manner with a limited number of parameters. A major advantage of SWMM compared to other models existing in the literature is its ability to simulate long periods with a reasonable calculation time, which is necessary to characterize the longterm functioning of the system.

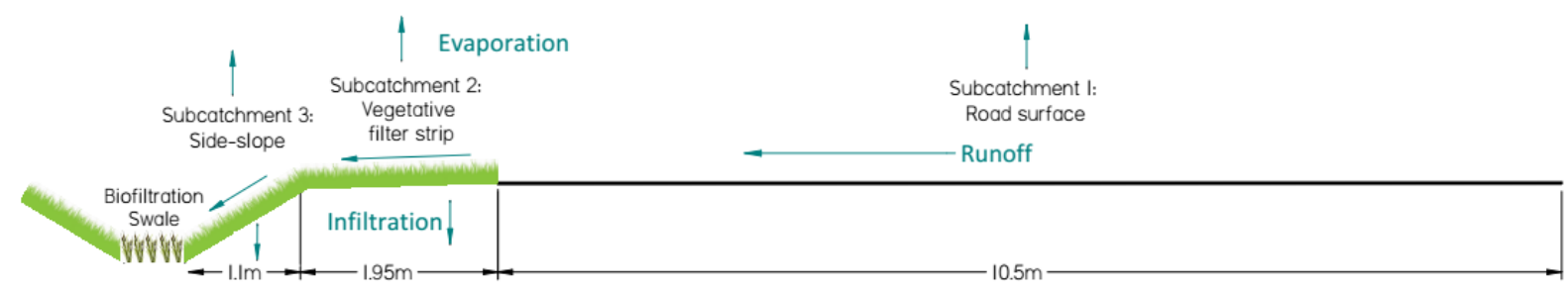

Figure 2: Geometry of the modeled system

The geometry of the system is presented in Figure 2; each sub-catchment is considered to be $48 \mathrm{~m}$ wide (note that width here is defined as in SWMM input to be the direction perpendicular to flow, not as width in VFS design guides, which define it as the VFW dimension in the direction of flow), the distance between two check dams in the swale. The road is represented as an impermeable sub-catchment, while the vegetative filter strip and side-slope are considered to be permeable sub-catchments, whose characteristics are presented in Table 1. Depression storage and roughness coefficient are typical values for vegetated surfaces (Rossman 2015). All simulations were carried out using Green-Ampt for infiltration modeling for two types of soil (silt loam similar to the typical topsoil and sandy loam similar to the filter medium) and two initial humidity conditions (humid water content equal to field capacity - and dry - water content equal to the lowest value measured on site, see Table 2). The model assumes a homogenous soil column of infinite depth and is unable to take into account 
different drainage conditions. Soil textures were measured experimentally on samples taken in January 2016, hydraulic conductivity was based on field measurements (Kanso 2015); initial water deficits were based on continuous field soil moisture content measurements and the suction heads associated were derived from soil water-retention curves estimated from soil properties using the Rosetta module of the model Hydrus (Schaap et al. 2001). In order to have an idea of the behavior of the system for a less permeable soil, the long-term simulation was also carried out for a clay soil, for which the parameters are typical values for the soil type (Rossman 2015).

Simulations were run using three types of rain data: constant-intensity rainfalls, individual rain events and a 4year rainfall record. The constant-intensity rainfalls tested each have a total rainfall of $18 \mathrm{~mm}$ and different intensities: $1,3,4.5,6,9 \mathrm{~mm} / \mathrm{h}$, corresponding to $4.0,12.5,18.8,25.2,37.9 \mathrm{~mm} / \mathrm{h}$ in equivalent rainfall intensity ( $i_{\text {eq }}$, Eq. 1,). For comparison, around $55 \%$ of rainfall in Paris occurs at an intensity of less than $3 \mathrm{~mm} / \mathrm{h}$ and $75 \%$ at less than $9 \mathrm{~mm} / \mathrm{h}$ (Van De Voorde, 2012). These simulations were used to examine the effect of intensity on the overall system's runoff coefficient $\left(C_{R}\right.$ or the total proportion of water reaching the biofiltration swale, Eq. 2) as well as the model's sensitivity to difficult-to-estimate parameters (depression storage, Manning's $\mathrm{n}$, hydraulic conductivity). Sensitivity analysis was carried out by varying a single parameter across the range of possible values while fixing all other parameters at the best estimate.

$i_{\text {eq }}=i_{\text {rainfall }} \frac{C_{R, \text { road. }} S_{\text {road }}+S_{V F S}+S_{\text {side slope }}}{S_{V F S}+S_{\text {side slope }}}$

where $i_{\text {rainfall }}$ is rainfall intensity, $C_{R, \text { road }}$ is the runoff coefficient for the road surface calculated by the model for a given intensity, $S_{\text {road }}, S_{V F S}$ and $S_{\text {side-slope }}$ are the projected surface areas of the road, VFS and side-slope respectively.

$C_{R}=\frac{V_{\text {outlet }, \text { side slope }}}{h_{\text {rain }}\left(S_{\text {road }}+S_{V F S}+S_{\text {side slope }}\right)}$

where $V_{\text {outlet,side slope }}$ is runoff volume exiting the side-slope of the system and entering the biofilter, $h_{\text {rain }}$ is total rainfall, $S_{\text {road, }} S_{V F S}$ and $S_{\text {side slope }}$ are the surface areas of the road, vegetative filter strip and side-slope respectively.

Data from an on-site rain gage at a 6-minute time step for four individual rain events, varying in both intensity and total rainfall, was used in order to better understand the variability in $C_{R}$. The fraction of road runoff in the biofilter $\left(F_{R R}\right.$, eq. 3$)$, a coefficient taking into account the dilution of the road runoff at the bottom of the 


\section{RESULTS AND DISCUSSION}

\section{Constant-Intensity Simulations}

Constant-intensity simulations revealed that the runoff coefficient for the road + vegetative filter strip + sideslope system is extremely dependent on both rainfall intensity and the hydraulic conductivity of soil (Figure 3).

biofiltration swale, was also calculated for each rain event. For its calculation, the pollutant load from direct rainfall was considered to be negligible. It was assumed that direct rainfall and runon were well-mixed on each subcatchment, so that concentrations in infiltration and in subcatchment runoff were equal to each other.

$F_{R R}=\frac{V_{\text {runoff }, \text { road }}}{V_{\text {runoff,road }}+h_{\text {rain }}\left(S_{V F S}\right)} \cdot \frac{V_{\text {runof }, V F S}}{V_{\text {runoff }, V F S}+h_{\text {rain }}\left(S_{\text {side slope }}\right)} \cdot \frac{V_{\text {runof }, \text { side slope }}}{V_{\text {runoff, side slope }}+h_{\text {rain }}\left(S_{\text {biofilter }}\right)}$

where $V_{\text {runoff,road }}, V_{\text {runoff, VFs, }}$ and $V_{\text {runoff, side slope }}$ are volumes running off of the road, vegetative filter strip and sideslope respectively, $h_{\text {rain }}$ is total rainfall over the event, and $S_{V F S}, S_{\text {side slope }}$ and $S_{\text {biofiter }}$ are surface areas of the vegetative filter strip, side-slope and biofilter respectively.

\begin{tabular}{|c|c|c|c|}
\hline Subcatchment & Road & $\begin{array}{c}\text { Vegetated } \\
\text { Filter Strip }\end{array}$ & $\begin{array}{c}\text { Side- } \\
\text { slope }\end{array}$ \\
\hline Slope (\%) & 2 & $\begin{array}{c}5 \\
(1-10)\end{array}$ & 66 \\
\hline Length (m) & 10.5 & $\begin{array}{c}1.95 \\
(0.5-3.5)\end{array}$ & $\begin{array}{c}1.10 \\
(0-1.5)\end{array}$ \\
\hline $\begin{array}{c}\text { Depression } \\
\text { Storage (mm) }\end{array}$ & 1 & $\begin{array}{c}5 \\
(1-15)\end{array}$ & $\begin{array}{c}5 \\
(1-15)\end{array}$ \\
\hline $\begin{array}{c}\text { Roughness } \\
\text { coefficient }\end{array}$ & 0.011 & $\begin{array}{c}0.15 \\
(0.1-0.63)\end{array}$ & $\begin{array}{c}0.15 \\
(0.1-0.63)\end{array}$ \\
\hline
\end{tabular}

Table 1: VFS and side-slope model parameters

\begin{tabular}{|c|c|c|c|c|}
\hline \multicolumn{2}{|c|}{ Soil type } & $\begin{array}{c}\text { Silt } \\
\text { loam } \\
\text { (native } \\
\text { soil) }\end{array}$ & $\begin{array}{c}\text { Sandy } \\
\text { loam } \\
\text { (filter } \\
\text { medium) }\end{array}$ & Clay \\
\hline \multirow{2}{*}{$\begin{array}{c}\text { Hydraulic } \\
\text { conductivity (mm/h) }\end{array}$} & $\begin{array}{c}13.8 \\
(1-36)\end{array}$ & $\begin{array}{c}23.8 \\
(10-28)\end{array}$ & 0.254 \\
\hline $\begin{array}{c}\text { Suction } \\
\text { head (mm) }\end{array}$ & Humid & 91.1 & 56.3 & 316.2 \\
\cline { 2 - 5 } & Dry & 93.7 & 56.5 & 316.2 \\
\hline \multirow{2}{*}{$\begin{array}{c}\text { Initial water } \\
\text { deficit (\%) }\end{array}$} & Humid & 17 & 17 & 7.5 \\
\cline { 2 - 5 } & Dry & 33 & 29 & 27.5 \\
\hline
\end{tabular}

Table 2: Green-Ampt parameters for soils
Values in italic are best estimates for the site; those in parentheses represent the range used for sensitivity analysis.

Finally, a four-year-long, 5-minute time-step rain record (June 2008-May 2012) from the Paris region was used to evaluate the volumes of water treated by each part of the system over a long period. A corresponding daily evapotranspiration record for the same period was used for evaporation modeling. This record was also used to evaluate the effect that design parameters (filter width, soil type) might have on the overall water balance. Indeed, for the silt loam soil, the range of hydraulic conductivity values measured in the field is so wide 
0.76. We observe that runoff only occurs when equivalent rainfall intensity $\left(i_{e q}\right)$ is superior to the hydraulic conductivity $\left(K_{s}\right)$ of the soil. It can also be noticed that a slightly higher $i_{e q}$ is necessary to achieve a non-zero runoff coefficient for the silt loam than the sandy loam. This is because the silt loam's greater suction head rates.
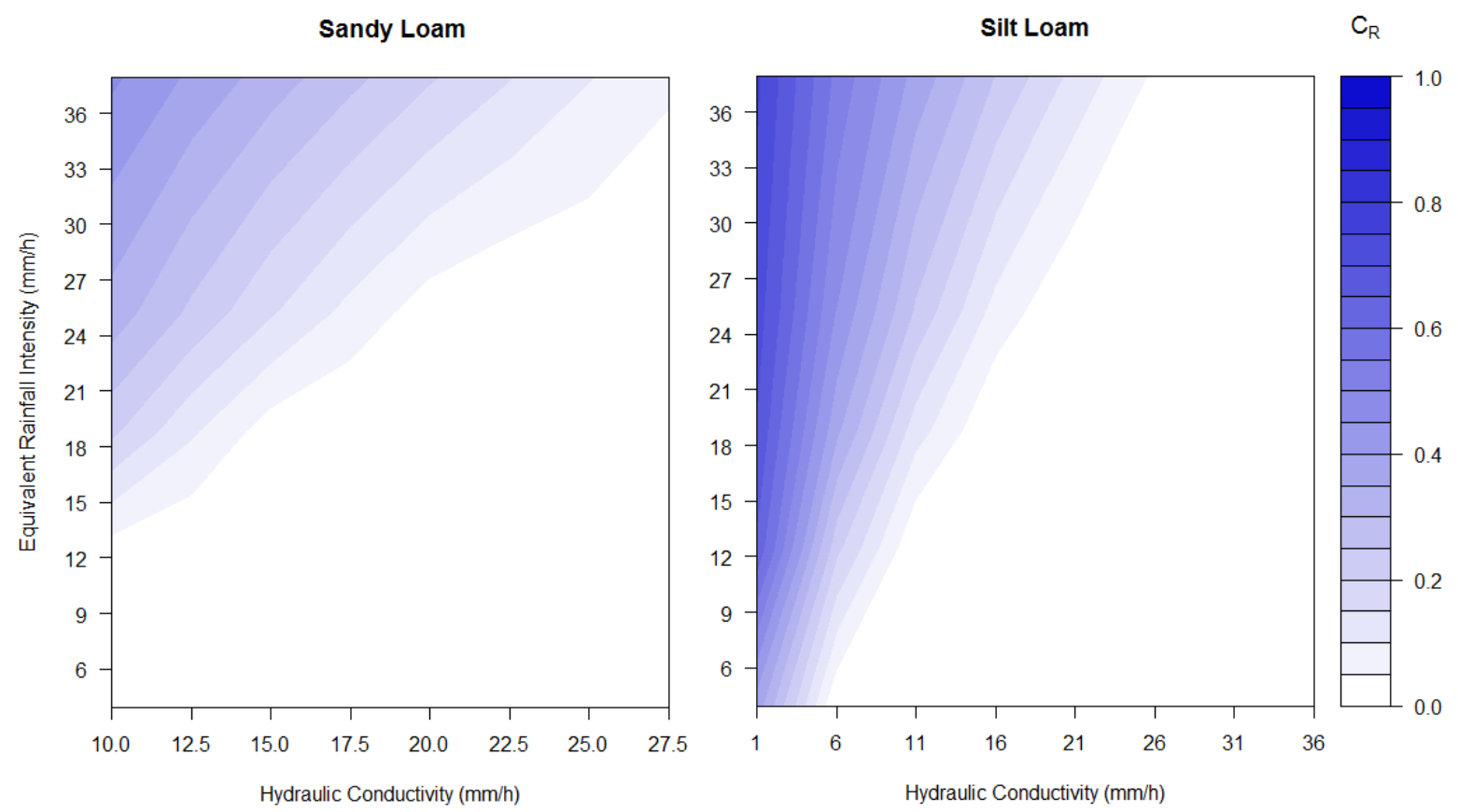

Figure 3 : Runoff coefficient in terms of hydraulic conductivity and equivalent rainfall intensity for (a) sandy loam and (b) silt loam

In terms of system design, these results indicate that soil type and compaction, as well as the ratio of the surface area of a vegetative filter strip to that of the impermeable, runoff-generating area will strongly affect the proportion of runoff infiltrated in a VFS. In addition, the importance of rainfall intensity means that the system's runoff behavior also depends on the precipitation patterns of the location where it is installed. In a climate like that of Paris, characterized by frequent but generally low-intensity rainfall, one would expect less runoff than in a climate with more intense rain events. the system of up to $15 \%$ of total rainfall volume across the range of possible values (Table 3 ). In the model, depression storage begins to fill up only when $i_{\text {eq }}$ exceeds the infiltration rate. Once the depression storage is 

parameters, as they effectively do not play a role in runoff production but only in the rate at which it occurs. A limitation of the USEPA SWMM runoff model is its consideration that overland flow is evenly spread over the subcatchment. In reality, at higher slopes and velocities, flow would begin to concentrate, which would limit infiltration.

\begin{tabular}{|l|c|c|c|c|c|}
\hline \multicolumn{2}{|l|}{} & $\begin{array}{c}\text { Silt loam - } \\
\text { humid }\end{array}$ & $\begin{array}{c}\text { Silt loam - } \\
\text { dry }\end{array}$ & $\begin{array}{c}\text { Sandy loam - } \\
\text { humid }\end{array}$ & $\begin{array}{c}\text { Sandy loam - } \\
\text { dry }\end{array}$ \\
\hline Depression storage & $1-15 \mathrm{~mm}$ & $0.20-0.35$ & $0.08-0.23$ & $0.04-0.16$ & $0-0.09$ \\
\hline Roughness coefficient & $0.1-0.63$ & $0.30-0.31$ & $0.17-0.19$ & $0.12-0.13$ & $0.05-0.06$ \\
\hline VFS slope & $1-10 \%$ & $0.30-0.31$ & 0.18 & $0.12-0.13$ & $0.05-0.06$ \\
\hline
\end{tabular}

Table 3: Range of runoff coefficients obtained in sensitivity analysis for a rainfall intensity of $9 \mathrm{~mm} / \mathrm{h}$

Despite the simplified representation of this system in SWMM, sensitivity analysis leads to the same conclusions found by more complex models. Deletic (2001) found total runoff volume to be sensitive to hydraulic conductivity, but not very sensitive to slope, roughness coefficient or surface retention. Roughness coefficient and surface retention were most sensitive in an intermediate range of hydraulic conductivity values, wherein soil was fairly permeable but not so much so that all water infiltrated before reaching the end of the strip. Muñoz-Carpena et al. (1999) explained that runoff volume is very sensitive to hydraulic conductivity and somewhat sensitive to initial water content, while the roughness coefficient mainly has an effect on the time to peak of the hydrograph rather than the runoff volume. Akan and Atabay (2016) showed runoff volume to be sensitive to the ratio of hydraulic conductivity to rainfall intensity and somewhat sensitive to soil suction (a combination of suction head and initial water content). Slope and roughness coefficient, regrouped as a dimensionless coefficient related to Manning's equation, were sensitive only when this coefficient was small while hydraulic conductivity and soil suction were high.

\section{Individual Rain Event Simulations}

Characteristics of the simulated events and principal results of these simulations are presented in Table 4. The peak intensity of July 21, 2014 was the highest measured on site since recording began in 2012 - one would therefore expect it to have a relatively high runoff coefficient. Although these values $(0.25-0.35)$ are greater than those estimated for other, less intense rain events $(0-0.05)$, even in this case the majority of road runoff is treated by the vegetative filter strip + side-slope system rather than the biofilter. For the February and 
December events, characteristic of typical, low-intensity winter rain events in the Paris region, the quasi-

totality of runoff infiltrates before reaching the biofilter. For the April-May event, characterized by very high total rainfall and moderate peak intensity, a small fraction $(0-0.05)$ of runoff is treated by the biofilter. The soil's initial moisture conditions also play a role - less water runs off if the soil is initially dry. As would be expected, a VFS with sandy loam soil infiltrates more water than one with a less permeable silty loam soil. compared to that of the vegetative filter strip + side-slope system.

\begin{tabular}{|c|c|c|c|c|c|c|c|}
\hline Event date & $\begin{array}{l}\text { Total } \\
\text { rainfall } \\
(\mathrm{mm})\end{array}$ & $\begin{array}{l}\text { Duration } \\
\text { (h) }\end{array}$ & $\begin{array}{l}\text { 6-minute } \\
\text { Peak } \\
\text { Intensity } \\
(\mathrm{mm} / \mathrm{h})\end{array}$ & Soil & $\begin{array}{c}\text { Initial } \\
\text { conditions }\end{array}$ & $\begin{array}{c}\text { Runoff } \\
\text { coefficient }\end{array}$ & $\begin{array}{c}\text { Road runoff } \\
\text { fraction in } \\
\text { biofilter }\end{array}$ \\
\hline \multirow{4}{*}{$\begin{array}{l}\text { December } \\
17,2014\end{array}$} & \multirow{4}{*}{11.2} & \multirow{4}{*}{11.5} & \multirow{4}{*}{4} & \multirow{2}{*}{$\begin{array}{c}\text { Silt } \\
\text { loam }\end{array}$} & Humid & 0 & 0 \\
\hline & & & & & Dry & 0 & 0 \\
\hline & & & & \multirow{2}{*}{$\begin{array}{l}\text { Sandy } \\
\text { loam }\end{array}$} & Humid & 0 & 0 \\
\hline & & & & & Dry & 0 & 0 \\
\hline \multirow{4}{*}{ July 21, 2014} & \multirow{4}{*}{14.1} & \multirow{4}{*}{8.2} & \multirow{4}{*}{56} & \multirow{2}{*}{$\begin{array}{c}\text { Silt } \\
\text { loam }\end{array}$} & Humid & 0.35 & 0.60 \\
\hline & & & & & Dry & 0.29 & 0.57 \\
\hline & & & & \multirow{2}{*}{$\begin{array}{l}\text { Sandy } \\
\text { loam }\end{array}$} & Humid & 0.30 & 0.57 \\
\hline & & & & & Dry & 0.25 & 0.54 \\
\hline \multirow{4}{*}{$\begin{array}{l}\text { February 22- } \\
23,2015\end{array}$} & \multirow{4}{*}{12.9} & \multirow{4}{*}{9.3} & \multirow{4}{*}{6} & \multirow{2}{*}{$\begin{array}{c}\text { Silt } \\
\text { loam }\end{array}$} & Humid & 0.0014 & 0.012 \\
\hline & & & & & Dry & 0 & 0 \\
\hline & & & & \multirow{2}{*}{$\begin{array}{l}\text { Sandy } \\
\text { loam }\end{array}$} & Humid & 0 & 0 \\
\hline & & & & & Dry & 0 & 0 \\
\hline \multirow{4}{*}{$\begin{array}{l}\text { April } 30- \\
\text { May 1, } 2015\end{array}$} & \multirow{4}{*}{28.3} & \multirow{4}{*}{29.4} & \multirow{4}{*}{16} & \multirow{2}{*}{$\begin{array}{c}\text { Silt } \\
\text { loam }\end{array}$} & Humid & 0.05 & 0.22 \\
\hline & & & & & Dry & 0.02 & 0.11 \\
\hline & & & & \multirow{2}{*}{$\begin{array}{l}\text { Sandy } \\
\text { loam }\end{array}$} & Humid & 0.01 & 0.05 \\
\hline & & & & & Dry & 0 & 0 \\
\hline
\end{tabular}

Table 4 : Principal results of individual rain event simulations

$F_{R R}$ was found to be variable, covering the range $0-0.60$, meaning that even without any pollutant removal, concentrations reaching the biofilter will be at most $60 \%$ of those in road runoff and as little as $0 \%$, the latter case occurring when all runoff has infiltrated in the vegetative filter strip + side-slope part of the system. One part of this dilution comes from the increase in volume expected from direct rainfall on the permeable parts of the system as the surface of the road represents only $74 \%$ of the total surface of the studied system. However, $F_{R R}$ is always below 0.74 because some polluted water is lost to infiltration as it passes through the vegetative filter strip and side-slope, making the dilution of water remaining on the surface more significant. The extent of infiltration in the pretreatment system depends on event characteristics; low-intensity rainfall and initially dry soil conditions both tend to increase the proportion of infiltration, leading to a lower $F_{R R}$. As a result, the biofiltration swale inlet concentration cannot be extrapolated from road runoff concentration by any trivial 

concentration.

252

\section{4-year Rainfall Record Simulations}

Simulating the behavior of the system over a 4-year period allows a large range of precipitation events to be taken into account. Results were again used to calculate a long-term runoff coefficient, representative of the total proportion of rainfall handled by the vegetative filter strip + side-slope system over the period. $C_{R}$ was found to be $0.090-0.12$ for silty loam (depending on initial soil conditions) and $0.068-0.082$ for sandy loam. While data records enabling the validation of the model are not available, these results confirm field observations indicating that the ditch rarely receives runoff water, notably that standing water has only been observed in the ditch during one exceptional rain event since its construction, that plants requiring humid conditions have not survived and that non-zero flows measured in the drain beneath the ditch are exceedingly rare.

For all cases, $27 \%$ of total rainfall was evaporated directly from the road's surface, corresponding to initial losses for which no runoff is generated. For silt loam soil, the biofilter is expected to treat between $11-15 \%$ of the road runoff generated, while the other $85-89 \%$ would be treated by the vegetative filter strip + side-slope system. The swale's role is slightly less significant for sandy loam, as it will treat $8.6-10 \%$ of runoff as opposed to $89-90 \%$ treated by the vegetative filter strip + side-slope system. Therefore, a far greater proportion of the pollutant load will be managed by this part of the facility than by the biofilter. In terms of experimental design, this means that when studying the fate of pollutants, the greatest effort should be put into studying the VFS and side-slope part of the system rather than the biofilter itself.

\section{Discussion}

These results call for reflection in terms of the SuDS design. When the Compans system was planned, it was assumed that the pollutant load would mainly be handled by the biofilter, the filter strip acting only as a pretreatment, and special attention was paid when choosing its soil and plants in order to optimize pollutant retention and degradation. Less attention was given to the vegetative filter strip + side-slope part of the system. If pollution management is an objective, the retention and degradation of pollutants should be optimized in the part of the system handling the greatest load. Two solutions might allow for a more coherent 
design: either infiltration could be minimized on the filter strip by minimizing filter width and/or choosing and compacting a relatively impermeable soil or, as with the biofilter, properties of the filter strip could be chosen in order to optimize depollution in the soil. If the second solution is chosen, care must be taken to ensure that the infiltration of water in close proximity to the road does not pose a problem to its structure which may be

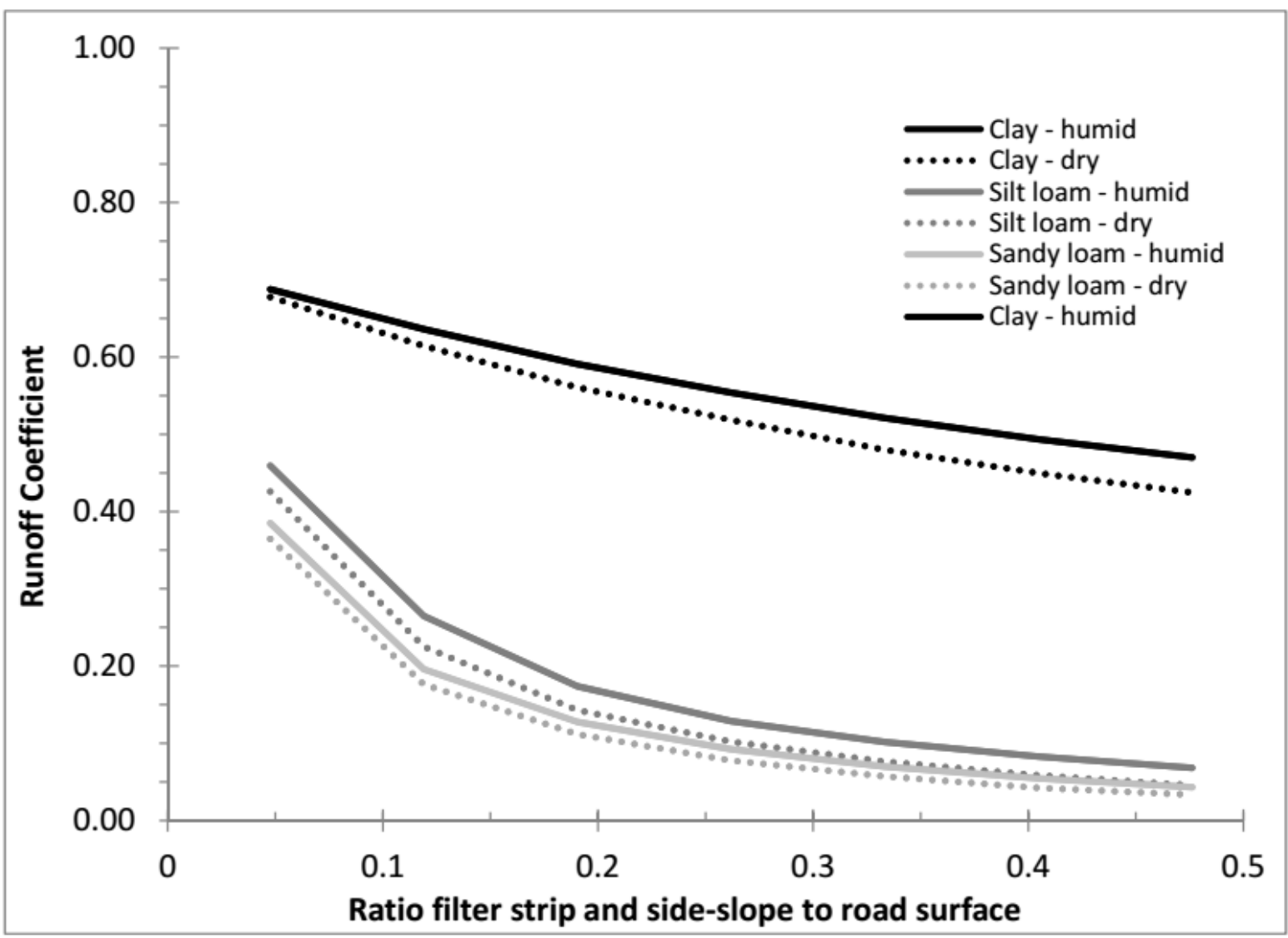

Figure 4 : Evolution of runoff coefficient with the vegetative filter strip + side-slope to road surface ratio

Figure 4 shows the runoff coefficient as a function of the vegetative filter strip + side-slope versus road surface ratio for three types of soil and two humidity assumptions. These calculations were carried out by varying the width of the VFS and side-slope across the range presented in Table 1. One can see that even a very narrow vegetative filter strip + side-slope combination with silt loam or sandy loam soil will infiltrate a substantial proportion of runoff. This proportion is quite sensitive to the surface ratio at lower values and becomes less 
accounts for a smaller volume. Because the clay soil has a very low permeability $(0.25 \mathrm{~mm} / \mathrm{h})$ compared with

that of the other soils, a greater proportion of water reaches the biofilter and the runoff coefficient is less sensitive to surface ratio. It also has a higher suction head, making the infiltration rate more sensitive to soil moisture conditions than the other soils. It should be noted that although clay would provide a low hydraulic conductivity, swelling clays should be avoided as their presence could lead to the formation of fissures and therefore preferential flows in dry conditions.

In the absence of data series allowing for the calibration and validation of the model, it is important to be aware of the sources of uncertainty within the model, associated with both the estimation of input parameters and with the model's simplifying hypotheses and limitations. The model's high sensitivity to soil hydraulic conductivity, which varies significantly between in situ measurements, makes this parameter a major source of model uncertainty. To a lesser extent, depression storage, which is estimated based on surface type and to which model results are somewhat sensitive, can also lead to model uncertainty. Although the estimation of Manning's coefficient is also quite uncertain, the insensitivity of the model to these parameters values makes it an insignificant source of uncertainty.

Another source of uncertainty in the model lies in its assumption that water is evenly spread across the surface of each sub-catchment and that all runoff from the road enters the vegetative filter strip. In reality, maintaining sheet flow in such a system is a challenge, especially in highly polluted catchments where sediment deposits can block water inflow at some points, leading to concentrated flows at others, which would lead, overall, to less infiltration. In Compans, it has also been observed since that the soil level has risen since the construction of the system in 2012 on the silt loam part of the system. The level of the vegetative filter strip is now a few millimeters higher than the level of the road, leading to lateral flows and smaller volumes of water entering the filter strip than expected. As a system ages, even very small evolutions in topography can lead to major differences in its real behavior from the theoretical behavior represented by the model, leading to significant uncertainty. In future work, it would be useful to develop methods for testing the hypothesis of sheet flow in the field. The US EPA SWMM Green-Ampt infiltration model also makes several simplifying hypotheses which can be a source of uncertainty. One limitation of this model is that there is no accurate mechanism for calculating 

days for the silt loam and 3.2 days for the sandy loam), soil moisture returns to its initial value, which is considered to be its minimal water content; it is therefore impossible to account for the variability of soil moisture conditions in a long-term simulation. Evaporation is only calculated for water on the soil surface. Another limitation is its assumption within a rain event of an infinite and homogenous soil column. In the case of Compans, the road's structure is present beneath a large portion of the silt loam vegetated road shoulder, which may limit infiltration during major storm events or especially wet periods. The shoulder made of sandy loam is drained at a depth of about $15 \mathrm{~cm}$; infiltration will not be limited in the same way for wet periods, but the Green and Ampt model's representation of both wetting and drying differs greatly from the real system's behavior. These limitations due to the Green and Ampt model are common to other vegetative filter strip models found in the literature (Akan and Atabay 2016; Deletic 2001; Muñoz-Carpena et al. 1999). Future work should attempt to better represent both evapotranspiration and the influence of the road structure and the drain on infiltration and flow of water in the soil.

\section{CONCLUSIONS}

A model of infiltration and runoff on the vegetative filter strip + side-slope portion of a VFS and biofiltration swale treatment train located in Compans, France was created in USEPA SWMM in order to gain a better understanding of the system's hydrologic behavior. factors influencing whether water is infiltrated or runs off toward the biofilter. As a consequence, systems of similar geometry located in different climates or having different soil types, may function very differently. In addition, this result underlines the importance of correctly characterizing a site's hydraulic conductivity when constructing a model; the heterogeneity of hydraulic conductivity within a given site can be an important source of uncertainty in the model. The runoff coefficient was found to be insensitive to sub-catchment slope and Manning's roughness coefficient and moderately sensitive to depression storage estimation. The vegetative filter strip + side-slope to road surface area ratio also has a significant effect on runoff coefficient; the more permeable the soil, the more sensitive results are to this factor. 
intensity is greater than the soil's saturated hydraulic conductivity. This is because runoff will only occur once

the depression storage is filled and depression storage will only begin to fill when the equivalent rainfall intensity surpasses the rate of infiltration, which will be equal to or greater than the saturated hydraulic conductivity (when the soil is unsaturated, a suction head is applied which will increase infiltration rate). The time necessary to fill the depression storage depends on the difference between equivalent rain intensity and the infiltration rate.

Simulation of four real rainfall events and a 4-year rainfall record revealed that the majority of road runoff is treated by the vegetative filter strip and side-slope of the biofiltration swale rather than the biofilter located beneath the swale. Therefore, the biofilter's pollutant removal efficiency plays a less significant role in the efficiency of the overall system than that of the vegetative filter strip and side-slope of the system. In terms of experimental design for evaluating pollutant removal efficiency, this means that it is more important to characterize treatment in the vegetative filter strip and side-slope part of the system than in the biofilter. In addition, it was found that road runoff reaching the biofilter would be strongly and variably diluted by rain falling directly on the system.

Results also have implications for SuDS design, as the system's current design, which aims to optimize pollutant retention and degradation in the biofilter but not in the vegetative filter strip + side-slope, is not coherent with its real hydraulic behavior. In reality, the system is more similar to that proposed by the Swiss Federal Road Office in which water is infiltrated and filters through the soil of an embankment slope after running off across a shoulder where infiltration is minimized (Piguet et al. 2009) than to a biofiltration swale.

This study highlights the importance of understanding the hydrologic behavior of a system before planning a water quality analysis. More generally, it shows the necessity of using a model, even a highly simplified one, to study the hydrologic behavior of a SuDS during the design process. If system hydraulic conductivity can be accurately estimated, US EPA SWMM can be a useful tool for predicting the hydrologic behavior of SuDS involving vegetative filter strips, thereby allowing water quality design to focus on the most relevant parts of the system. However, simplifications in its representation of hydrological processes (evapotranspiration, infiltration, surface flow) may lead to differences between modeled and real behavior under certain circumstances. In addition, the model represents the theoretical behavior of an idealized system - therefore, it 
paths or lateral flows due to an increase in the soil level.

377 The authors have several recommendations for future research. First, for the better understanding of SuDS treatment train behavior, analogous models should be developed and tested for other possible combinations of SuDS devices (a swale followed by stormwater biofilter, for example). Secondly, future work can contribute to improving the present model, notably by improving the representation of water once it is in the soil, including the representation of evapotranspiration and different drainage conditions. The model's uncertainty could also be reduced by developing recommendations for estimating a global hydraulic conductivity value from a series of experimental measurements.

Further in situ experimental monitoring would also be useful to improve understanding of real system behavior. The calibration and validation of the current model require continuous measurement of flows entering and leaving the system; this type of monitoring remains a technical challenge. In addition, it has been mentioned that sheet flow, which is usually an objective of filter strip design and is an assumption of the model, may be difficult to achieve in the field. The development of experimental methods for testing whether sheet flow is actually achieved would therefore be useful both in order to verify whether systems are functioning correctly and to evaluate the pertinence of models based on this assumption.

\section{ACKNOWLEDGEMENTS}

This study has been conducted within the framework of the Observatory of Urban Pollutants in Paris (OPUR) and the ROULEPUR research program. The authors gratefully acknowledge OPUR partners (AESN, SIAAP, CD92, CD93, CD94, Ville de Paris), ONEMA and the Seine Normandie Water Agency for financial support. We also acknowledge the Seine-et-Marne Departmental Council, and especially Eric Thomas and Tina Ratovelomanana, for their partnership and technical support.

\section{BIBLIOGRAPHY} 188-195. 
Auckland Regional Council 2003 Swale and filter strip design, construction and maintenance, in: Stormwater Management Devices: Design Guidelines Manual, Aukland, New Zealand.

Bäckström, M., Viklander, M., Malmqvist, P.-A. 2006 Transport of stormwater pollutants through a roadside grassed swale. Urban Water Journal, 3(2), 55-67.

Barrett, M.E., Walsh, P.M., Jr, J.F.M., Charbeneau, R.J. 1998 Performance of vegetative controls for treating highway runoff. Journal of Environmental Engineering, 124(11), 1121-1128.

Cavaillès, M.O., Criscione, S., Gigleux, M., Hurtevent, J., Servier, A., Valin, M. \& Van-Hauwaert, B. 2007 Pollution d'origine routière: Conception des ouvrages de traitement des eaux (Pollution from roadways: Designing water treatment systems), Guide technique de la service d'études techniques des routes et autoroutes (Technical guide from the service of technical studies for roads and highways), France.

CIRIA, 2015. The SuDS Manual (C753). London.

Gaillard, D., Ranchet, J., Bététerbide, J., Valin, M., Hurtevent, J., Costille, A., Cartoux, G., Marcaud, R., Limandat, A. 2006 Assainissement Routier (Road Sanitation), Guide technique de la service d'études techniques des routes et autoroutes (Technical guide from the service of technical studies for roads and highways), France.

Deletic, A. 2001 Modelling of water and sediment transport over grassed areas. Journal of Hydrology, 248(1), 168-182.

Dorchin, A., Shanas, U. 2010 Assessment of pollution in road runoff using a Bufo viridis biological assay, Environmental Pollution, 158(12), 3626-3633.

Fletcher, T.D., Shuster, W., Hunt, W.F., Ashley, R., Butler, D., Arthur, S., Trowsdale, S., Barraud, S., SemadeniDavies, A., Bertrand-Krajewski, J.-L., Mikkelsen, P.S., Rivard, G., Uhl, M., Dagenais, D., Viklander, M. 2014 SUDS, LID, BMPs, WSUD and more - The evolution and application of terminology surrounding urban drainage, Urban Water Journal, 12(7), 525-542.

Gironás, J., Roesner, L., Davis, J. 2009 Storm Water Management Model Applications Manual, US EPA, Cincinnati, Ohio, USA. 
Hatt, B., Morison, P., Fletcher, T., Deletic, A. 2009 Stormwater Biofiltration Systems: Adoption Guidelines, Monash University.

Hamel, P., Daly, E., Fletcher, T.D. 2013 Source-control stormwater management for mitigating the impacts of urbanisation on baseflow: A review, Journal of Hydrology, 485, 201-211. Kalmykova, Y., Björklund, K., Strömvall, A.-M., Blom, L. 2013 Partitioning of polycyclic aromatic hydrocarbons, alkylphenols, bisphenol A and phthalates in landfill leachates and stormwater, Water Research, 47(3), 1317-1328.

Kanso, T. 2015 Caractérisation hydrodynamique d’un accotement de voirie végétalisée (Hydrodynamic characterization of a vegetated road shoulder). Master's thesis, LEESU, Lebanese University, Beirut, Lebanon.

Kayhanian, M., Fruchtman, B.D., Gulliver, J.S., Montanaro, C., Ranieri, E., Wuertz, S. 2012 Review of highway runoff characteristics: Comparative analysis and universal implications, Water Research, 46(20), 66096624.

Leroy, M., Portet-Koltalo, F., Legras, M., Lederf, F., Moncond’huy, V., Polaert, I., Marcotte, S. 2016 Performance of vegetated swales for improving road runoff quality in a moderate traffic urban area, Science of The Total Environment, 566-567, 113-121.

Li, M.-H., Barrett, M.E., Rammohan, P., Olivera, F., Landphair, H.C. 2008 Documenting stormwater quality on Texas highways and adjacent vegetated roadsides, Journal of Environmental Engineering, 134(1), 4859.

Muñoz-Carpena, R., Parsons, J.E., Gilliam, J.W. 1999 Modeling hydrology and sediment transport in vegetative filter strips, Journal of Hydrology, 214(1-4), 111-129.

Piguet, P., Parriaux, A., Bensimon, M. 2009 Road runoff management using over-the-shoulder infiltration: realscale experimentation. Water Science \& Technology, 60(6), 1575-1587.

Rossman, L. 2015 Storm Water Management Model Reference Manual: Hydrology. US EPA, Cincinnati, Ohio, Etats-Unis.

Roy-Poirier, A., Champagne, P., Filion, Y. 2010 Review of bioretention system research and design: past, present, and future, Journal of Environmental Engineering, 136(9), 878-889. 
Sage, J., Berthier, E., Gromaire, M.-C. 2015 Stormwater Management Criteria for On-Site Pollution Control: A Comparative Assessment of International Practices, Environmental Management, 56(1), 66-80.

Schaap, M.G., Leij, F.J., van Genuchten, M.T. 2001 Rosetta: a computer program for estimating soil hydraulic parameters with hierarchical pedotransfer functions, Journal of Hydrology, 251(3-4), 163-176.Stagge, J.H., Davis, A.P., Jamil, E., Kim, H. 2012 Performance of grass swales for improving water quality from highway runoff, Water Research, 46(20), 6731-6742.

Stephens, D.B., Miller, M., Moore, S.J., Umstot, T., Salvato, D.J. 2012 Decentralized Groundwater Recharge Systems Using Roofwater and Stormwater Runoff, Journal of the American Water Resources Association, 48(1), 134-144.

Van De Voorde, A. 2012 Incidence des pratiques d'entretien des toitures sur la qualité des eaux de ruissellement : cas des traitements par produits biocides (Effect of maintenance practices on runoff water quality : the case of biocide treatments). Doctoral thesis. Université de Paris Est.

Winston, R.J., Hunt, W.F., Kennedy, S.G., Wright, J.D., Lauffer, M.S. 2012 Field Evaluation of Storm-Water Control Measures for Highway Runoff Treatment, Journal of Environmental Engineering, 138(1), 101111. 